\title{
Adenosine Deaminase Deficiency Without Immunodeficiency: Clinical and Metabolic Studies
}

\author{
WILLIAM BORKOWSKY, M.D., ANNE A. GERSHON, M.D., LOUIS SHENKMAN, M.D., AND \\ ROCHELLE HIRSCHHORN, M.D. ${ }^{(46)}$ \\ Departments of Medicine and Pediatrics, New York University School of Medicine, New York, New York, USA
}

\begin{abstract}
Summary
A child diagnosed at birth as deficient in red blood cell adenosine deaminase (ADA) but with substantial residual lymphocyte ADA has been evaluated for two and one-half years. The only immunologic abnormality observed was hypogammaglobulinemia during the fifth month of life. This was unexpected because children with total ADA deficiency either have severe combined immunodeficiency or selectively greater impairment of cellular than humoral immunity. The absence of severe combined immunodeficiency in this child was associated with normal lymphocyte content of ATP, dATP, and cyclic $3^{\prime} 5^{\prime}$-adenosine monophosphate, potentially toxic metabolites which are elevated in ADA-deficient immunodeficient children.
\end{abstract}

\section{Speculation}

Partial deficiency of lymphocyte adenosine deaminase, although sufficient for cell-mediated immune function, may exaggerate physiologic conditions that favor decreased immunoglobulin synthesis. The substance(s) responsible for this effect are probably adenosine metabolites which are of undetermined nature.

Severe combined immunodeficiency (SCID), when untreated, is a fatal disorder of infancy characterized by deficits of both humoral and cellular immunity (34). An inherited deficiency of the enzyme adenosine deaminase (ADA) has been found in up to $50 \%$ of patients with the autosomal recessive form of this disorder. To date, children from approximately 30 families have been described with ADA deficiency and SCID. All of these children have had impaired immune function, usually apparent by 6 months of age. They were identified because of persistent or recurrent infections or a previously affected sibling $(1,11,15,22$, 30). Approximately $85 \%$ of these ADA-deficient patients are indistinguishable from non-ADA-deficient patients with SCID, but approximately $15 \%$ have a more profound deficit of cellular than of humoral immunity $(15,16,30)$.

Only two immunologically and/or clinically normal individuals (both !Kung tribesmen from the Kalahari desert) (24) with ADA deficiency have been identified in spite of extensive population surveys directed at determining frequencies of the genetically polymorphic forms of ADA. We report here immunologic and clinical studies in a black American child found to lack ADA during the New York State program of screening of normal neonates for inherited disorders who has remained immunocompetent for over 2 years.

\section{CASE HISTORY}

M. H. was the first child of a nonconsanguineous mating who was delivered prematurely at 8 months of gestation by caesarian section because of placenta previa. The baby required intubation and resuscitation at birth. Physical examination was normal except for bilateral polydactyly and hypospadias. (His father also had bilateral polydactyly.) An IVP demonstrated an obstruction at the left ureteropelvic junction and possible vesicoureteral reflux with minimal dilation of the calyces. A chest $x$-ray during the first wk of life suggested a right lower lobe infiltrate which resolved in 2 days while the child was on antibiotic therapy. His course was uneventful except for anemia, for which he was transfused with $40 \mathrm{cc}$ of routinely prepared packed red blood cells from a male donor.

Routine New York State neonatal screening for inherited disorders revealed a deficiency of red blood cell ADA. After the diagnosis of ADA deficiency was made, the patient was admitted to Bellevue Hospital, placed in reverse isolation, and observed for possible graft-versus-host reaction secondary to the blood transfusion. Physical examination at one month of age was unchanged. Normal tonsillar tissue was present, and no bony or cartilaginous abnormalities were found on physical examination or $\mathrm{x}$-ray. There was a normal thymic shadow. His subsequent course was marked by absence of any evidence of graft-versus-host response. He was placed in reverse isolation and given oral mycostatin pending further evaluation of his immune function. Informed consent was obtained for further studies.

\section{CLINICAL COURSE}

On three separate occasions when the baby was between 5 and 6 months of age and in reverse isolation, an indurated furuncle approximately one $\mathrm{cm}$ in diameter appeared on different areas of his face. On each occasion a penicillin-sensitive staphylococcus aureus was isolated from the lesion, but blood cultures were negative. The furuncles were accompanied by development of prominent posterior and anterior cervical lymphadenopathy, but they resolved rapidly following treatment with incision, drainage, and/or oral dicloxacillin therapy. Examination of the purulent material revealed many granulocytes with engulfed bacteria. These infections corresponded with a period of hypogammaglobulinemia (Table 1). At 8 months of age because no significant immunologic abnormalities appeared to be present, the child was removed from reverse isolation.

Reevaluation of the genitourinary tract at 10 and 17 months showed a left nonprogressive calyceal dilation. Vesicoureteral reflux seen at 10 months was not noted at 17 months. Urine specific gravities revealed normal renal concentrating and diluting abilities. His creatinine clearance was minimally compromised (45 $\mathrm{ml} / \mathrm{min} / 1.73 \mathrm{~m}^{2}$ ) at 10 months but was well within normal limits at 17 months.

The patient's growth, height, and weight have progressed from the third to 25 th percentile at 20 months. His development has been normal for age with no obvious detrimental effect of the prolonged reverse isolation on his social and psychologic development. He is an alert, responsive, and very engaging child.

His clinical course at home, in a large extended family which also includes five school-age children, has been unremarkable until 36 months of age, except for five episodes of otitis media with fever between 14 and 20 months. A sixth febrile episode with 
Table 1. Cumulative white blood cell counts

\begin{tabular}{|c|c|c|c|c|}
\hline & \multicolumn{2}{|c|}{ During the first year of life $(n=71)$} & \multicolumn{2}{|c|}{ During the second year of life $(n=14)$} \\
\hline & Cells $/ \mathrm{mm}^{3}$ & Range & Cells $/ \mathrm{mm}^{3}$ & Range \\
\hline Total white blood cells & $9,801 \pm 2,384^{1}$ & $4,900-17,900$ & $10,100 \pm 2,641$ & $5,200-14,700$ \\
\hline Total lymphocytes & $7,071 \pm 999$ & $2,856-12,150$ & $6,606 \pm 1,818$ & $2,700-9,000$ \\
\hline $\begin{array}{l}\text { Total atypical lympho- } \\
\text { cytes }\end{array}$ & $330 \pm 351$ & $0-1,170$ & $101 \pm 202$ & $0-840$ \\
\hline Total eosinophils & $542 \pm 394$ & $0-2,000$ & $303 \pm 202$ & $0-640$ \\
\hline
\end{tabular}

${ }^{1}$ Mean \pm S.D.

cough was associated with a perihilar infiltrate; a similar illness was present in other family members at that time. All of these illnesses responded promptly to ampicillin therapy or resolved spontaneously.

\section{MATERIALS AND METHODS}

\section{IMMUNOLOGIC EVALUATION}

Serum immunoglobulins were measured by radial immunodiffusion in commercial plates (Bering Diagnostics, Sommerville, N. J.). IgE was measured by radioimmunoassay. Immunoglobulin subclasses were kindly measured by Dr. S. Litwin. Serum antibody titres to polio types 1, 2, and 3 and diptheria toxin were determined by the Center of Disease control, Atlanta, GA. Complement components $\left(\mathrm{C}_{3}, \mathrm{C}_{4}, \mathrm{Clq}\right.$, and properdin) were graciously assayed by Dr. Irma Gigli. Enumeration of lymphocyte subpopulation: Tcells were enumerated after the method of Jondal et al. (25), complement receptor-bearing lymphocytes by the method of

Bianco et al. (4), and immunoglobulin-bearing lymphocytes by the method of Winchester and Ross (43) using a goat anti-human immunoglobulin-fluoresceinated antibody (Cappel, Inc., Cochronville, PA) and latex ingestion to exclude macrophages.

In Vitro Studies of Peripheral Blood Lymphocyte Responses. For measurement of responses to mitogens, Ficoll-Hypaque-purified mononuclear cells were suspended in Roswell Park Memorial Institute Medium 1640 supplemented with $20 \%$ heat-inactivated horse serum and cultured as previously described (17). Responses to antigens were measured as described by Cohen et al. (8). Additionally, tetanus toxoid dialyzed free of preservative (Massachusetts Public Health Biologic Laboratory) was used at final concentrations of 0.9 and $9 \mathrm{Lf} / \mathrm{ml}$. Responses to allogenic lymphocytes were measured using stimulator cells which had been incubated at $37^{\circ} \mathrm{C}$ for $30 \mathrm{~min}$ with mitomycin $\mathrm{C}(25 \mu \mathrm{g} / \mathrm{ml})$ (Sigma Chemical Co., St. Louis, MO) and washed extensively. Stimulator cells $\left(7.5 \times 10^{4}\right)$ in $0.1 \mathrm{ml}$ media containing $15 \%$ pooled $\mathrm{AB}$ serum were added to wells containing $0.1 \mathrm{ml}$ of $7.5 \times 10^{4}$ responding cells. Six days later, $0.03 \mu \mathrm{Ci}$ of $\left[{ }^{14} \mathrm{C}\right]$ thymidine (New England Nuclear; specific activity $\sim 50 \mu \mathrm{Ci} / \mathrm{nmole}$ ) was added to each well for 8 to $18 \mathrm{hr}$. Cells were then harvested on glass fiber filters, and the radioactivity incorporated was counted in a liquid scintillation counter. Skin tests: $0.1 \mathrm{ml}$ of diphtheria toxin and of diphtheria toxoid (Massachusetts Public Health Biologic Laboratories) were injected at different sites, and the diameters of induration and erythema were measured at 2, 6, 24, and $48 \mathrm{hr}$ at the toxoid site and at 24,48 , and $144 \mathrm{hr}$ at the toxin site. Streptokinasestreptodornase $(\mathrm{SK}-\mathrm{SD})(0.1 \mathrm{ml})$ (Varidase Lederle Laboratories, Pearl River, N.Y.), candida extract (Hollister Stier Laboratories, Los Angeles, CA), and purified protein derivative of tuberculin (PPD) intermediate strength were injected ID and measured at 24 and $48 \mathrm{hr}$. Sensitization and challenge with dinitrochlorobenzene (DNCB) were performed after the method of Catalona et al. (6).

\section{BIOCHEMICAL MEASUREMENTS}

Adenosine deaminase activity of erythrocytes and lymphocytes was determined as previously described (18) based upon the linked assay of Hopkinson et al. (23) but using $1.3 \mathrm{mM}$ substrate at $37^{\circ} \mathrm{C}$. Cyclic adenosine $3^{\prime}: 5^{\prime}$-monophosphate (cyclic AMP) content of
Table 2. Serum immunoglobulins ${ }^{1}$

\begin{tabular}{clcc}
\hline $\begin{array}{c}\text { Age } \\
(\mathrm{mos} .)\end{array}$ & \multicolumn{1}{c}{ IgG } & IgM & IgA \\
\hline 1 1/2 & $400(450-1,188)^{2}$ & $70(19-75)$ & $0(3-17)$ \\
2 & $340(313-825)$ & $40(25-100)$ & $15(8-44)$ \\
3 & $280(263-688)$ & $40(29-119)$ & $40(11-57)$ \\
5 & $125(263-713)$ & $60(34-138)$ & $25(13-71)$ \\
& $160(263-713)$ & $45(34-138)$ & $30(13-71)$ \\
6 & $440(281-763)$ & $55(36-144)$ & $15(14-76)$ \\
8 & $440(325-875)$ & $40(39-156)$ & $25(15-88)$ \\
10 & $500(388-1,025)$ & $50(41-169)$ & $30(17-101)$ \\
16 & $840(484-1,300)$ & $115(54-206)$ & $50(26-147)$ \\
19 & $900(538-1,400)$ & $165(54-206)$ & $71(26-147)$ \\
\hline
\end{tabular}

${ }^{1}$ Values recorded in $\mathrm{mg} \%$.

${ }^{2}$ Numbers in parenthesis, statistical variation $(0.6 \mathrm{X}$ to $1.6 \mathrm{X})$ in normal children.

mononuclear cells was measured after the method of Gilman (12). ATP content of Ficoll-Hypaque-purified mononuclear cells was determined by the method of Beutler (3). Deoxy-ATP content of lymphocytes was determined on $70 \%$ methanol extracts by the method of Solter and Handschumacher (40) as previously described.

\section{RESULTS}

\section{IMMUNOLOGIC EVALUATION}

White Cell Counts. The total white cell count in the patient's first year of life averaged 9,800 (Table 1) with a range from 4,900 to 17,900 . The total lymphocyte count has averaged 7,071 and has always been greater than 4,000 except during the occasional febrile episodes in the first year of life when the total lymphocyte count fell briefly to approximately 2,500. Random esterase stains of white blood cells showed an average of $5 \%$ monocytes. Although "atypical" lymphocytes were rarely noted in the first 3 months of his hospitalization, they became more frequent and were a regular finding during the last 3 months of his hospitalization. Eosinophilia was noted during his first month of hospitalization and became more prominent after 3 months of age. The mean eosinophil count was $542 \pm 394$ cells $/ \mathrm{mm}^{3}$ with an occasional peak to 1,200 cells $/ \mathrm{mm}$ and dropping down to zero during periods of illness. During the second year of life, total lymphocytes remain normal, the atypical lymphocytes are no longer seen and eosinophiles remain intermittently elevated.

Immunoglobulin and Antibody Studies. Normal IgG levels, presumably due to passively transferred antibody, were present at 6 wk of age. These declined as expected, but reached a nadir of 125 to $160 \mathrm{mg} \%$ between 5 and 6 months of age, which was well below normal. These levels then rose (Table 2), and his current IgG, IgM, and IgA levels fall within normal limits. Serum IgE (1.7 IU/ $\mathrm{ml})$ at 12 months was within normal range. Serum immunoelectrophoresis did not suggest restricted heterogeneity, and determination of $\mathrm{IgG}$ subclasses at age 9 months revealed normal distribution. Despite the transient hypogammaglobulinemia, he subsequently showed rising titres of antibody following immunization with diphtheria-tetanus and Salk polio vaccine. Antibody to tet- 
Table 3. Lymphocyte subpopulations ${ }^{1}$

\begin{tabular}{cccccr}
\hline & \multicolumn{2}{c}{ T-cells } & & \multicolumn{2}{c}{ B-cells } \\
\cline { 2 - 3 } \cline { 5 - 6 } Age (mos.) & $\%$ & Total & & $\%$ & Total \\
\hline $11 / 4$ & 21 & 3,600 & & $43^{2}$ & \\
5 & 56 & 3,000 & & & \\
8 & 49 & 3,300 & & $15^{3}$ & 1,000 \\
13 & 71 & 5,427 & & $23^{3}$ & 1,760 \\
16 & 66 & 5,966 & & $7^{3}$ & 633 \\
24 & 55 & 4,400 & & $15^{3}$ & 1,200 \\
Normal & $55-75$ & & & $5-15$ & \\
\hline
\end{tabular}

${ }^{1}$ Cells $/ \mathrm{mm}^{3}$.

${ }^{2} \mathrm{EAC}$ rosettes.

${ }^{3}$ Surface immunoglobulins.

Table 4. Lymphocyte response to mitogens ${ }^{1}$ measured by incorporation of $[\mathrm{H}$ H]thymidine

Mitogen

\begin{tabular}{cccc} 
& $\begin{array}{c}\text { Phytohemagglu- } \\
\text { tinin }\end{array}$ & Concanavalin A & $\begin{array}{c}\text { Pokeweed } \\
\text { mitogen }\end{array}$ \\
\hline Patient & $46,258 \pm 18,493$ & $25,779 \pm 11,449$ & $13,529 \pm 7,218$ \\
& $n=14$ & $n=9$ & $n=9$ \\
Normals & & & \\
Infants & $32,824 \pm 9,909$ & $13,404 \pm 6,508$ & $14,051 \pm 4,085$ \\
& $n=4$ & $n=4$ & $n=4$ \\
Adults & $27,540 \pm 8,657$ & $12,542 \pm 7,429$ & $11,603 \pm 6,526$ \\
& $n=14$ & $n=10$ & $n=11$ \\
\hline
\end{tabular}

${ }^{1}$ CPM's $\left[{ }^{3} \mathrm{H}\right]$ thymidine incorporated at 64 to $72 \mathrm{hr}$ of culture.

Table 5: Lymphocyte response to PHA measured by incorporation of $\left[{ }^{14}\right.$ C]leucine ${ }^{1}$ and ratio of thymidine to leucine incorporation

Ratio of thymidine: leucine incorporation

\begin{tabular}{crrrr} 
Age (mos.) & Patient & Normal & Patient & Normal \\
\hline 3 & 659 & 980 & 12.4 & 9.4 \\
4 & 6,355 & 1,798 & 13.3 & 15.4 \\
6 & 1,322 & 412 & 9.7 & 5.6 \\
8 & 2,641 & 1,605 & 13.8 & 13.8 \\
10 & 3,418 & 4,426 & 11.0 & 6.1 \\
15 & 9,373 & 6,748 & 4.7 & 5.5 \\
17 & 7,092 & 9,331 & 7.1 & 3.0 \\
18 & 12,139 & 10,799 & 4.1 & 3.3 \\
\hline
\end{tabular}

${ }^{1}$ CPM's $\left[{ }^{14} \mathrm{C}\right]$ leucine incorporated into trichloroacetic acid-precipitable material at 64 to $72 \mathrm{hr}$ of culture. anus was 5 hemagglutination units/ml (normal, 1 to 5 units). Diphtheria antibody titres were 0.093 hemolytic units $/ \mathrm{ml}$ following the second immunization and 0.75 units following the third immunization (normal, 1 to 5), confirming a negative Schick test. Antibody to polio viruses 1, 2, and 3 were all equal to or greater than 1:64. Isoagglutinin titres of $1: 64$ to blood group $\mathrm{B}$ were present. Complement components $\left(\mathrm{C}_{3}, \mathrm{C}_{4}, \mathrm{Clq}\right.$, and properdin) were within normal limits.

Evaluation of Cell Surface Markers. T-lymphocytes were low at 6 wk of age. However, subsequent determination at 5, 8, 13, and 16 months were all within normal limits (Table 3 ). B-lymphocytes were increased initially but fell gradually to normal at 16 months of age (Table 3 ).

Mitogen and Mixed Lymphocyte Responses. The patient's lymphocytes showed normal responses to phytohemagglutinin, pokeweed mitogen, and concanavalin A during his entire course (Table 4) both prior to the first transfusion at one month of age and following loss of detectable ADA activity in the red blood cells. To evaluate the possibility that the normal or slightly increased thymidine incorporation might be secondary to adenosineinduced depletion of pyrimidine pools, mitogen stimulation was also determined measuring incorporation of $\left[{ }^{3} \mathrm{H}\right]$ leucine into protein. These results were also similar to those of the normal controls (Table 5). Mixed lymphocyte responses were present at 2, 8, 10, and 18 months of age against a variety of donors.

In Vitro Cellular Responses to Immunizing Antigens. There was no lymphocyte response to diphtheria, tetanus, or candida antigens at 2 months of age, prior to immunization (table 6). Two wk after the second immunization ( 6 months of age), the patient's lymphocytes demonstrated a minimal response (3.1 stimulation index) to tetanus toxoid at $9 \mathrm{Lf}$ units $/ \mathrm{ml}$. Two months following his third immunization, he showed responses at 0.9 and $9 \mathrm{Lf}$ tetanus toxoid units/ml with a stimulation index of 11 at the higher antigen dose, but no response to SK-SD, candida, or PPD. By 18 months of age, he had detectable in vitro responses to SKSD, candida, diphtheria, and tetanus antigens (Table 6).

Skin Testing. One month following his third immunization with diphtheria-tetanus, the patient was skin tested with Schick toxin and toxoid, candida, SK-SD, trichophyton, and intermediate strength PPD. No erythema or induration were noted to trichophyton, SK-SD, PPD, or candida at either 24 or $48 \mathrm{hr}$. In contrast, there was a $15-\mathrm{x} 8-\mathrm{mm}$ area of both erythema and induration at the site of intradermally injected toxoid after $48 \mathrm{hr}$. No reaction was noted at the toxin site. The patient was also sensitized with 1 $\mathrm{mg}$ of DNCB and rechallenged 6 wk later with $50 \mu \mathrm{g} \mathrm{DNCB}$ to further evaluate delayed skin hypersensitivity. A $1-x 1-\mathrm{cm}$ pink, very slightly raised lesion with tiny vesicles was noted $24 \mathrm{hr}$ later, increased till $48 \mathrm{hr}$, and then resolved.

\section{BIOCHEMICAL DETERMINATIONS}

Red cell ADA activity measured prior to transfusion was barely detectable and was not different from that in other ADA-deficient

Table 6. Lymphocyte response to antigens ${ }^{1}$

\begin{tabular}{|c|c|c|c|c|c|c|c|c|}
\hline & \multicolumn{8}{|c|}{ Age (mos.) } \\
\hline & 2 & 6 & 9 & 11 & 13 & 17 & 18 & 21 \\
\hline Control & 162 & 186 & 492 & 110 & 1,596 & 426 & 196 & 49 \\
\hline \multicolumn{9}{|l|}{$\Gamma_{\text {etanus toxoid }}^{2}$} \\
\hline $9.0 \mathrm{Lf} / \mathrm{ml}$ & 175 & 582 & 1,645 & 5,083 & 5,601 & & & \\
\hline $0.9 \mathrm{Lf} / \mathrm{ml}$ & & 270 & 5,192 & 3,131 & & 3,153 & 1,297 & 2,228 \\
\hline Candida & 123 & & 874 & & 1,225 & & 1,134 & \\
\hline SK-SD & & & 650 & & 1,369 & & 1,301 & \\
\hline PPD & & & 778 & & 2,403 & & & \\
\hline \multicolumn{9}{|l|}{ Diptheria toxoid ${ }^{2}$} \\
\hline$(0.08$ Lf) & & & & & 7,456 & 3,433 & 2,096 & 464 \\
\hline
\end{tabular}

${ }^{1} \mathrm{CPM}$ 's $\left[{ }^{14} \mathrm{C}\right]$ thymidine incorporated at $126-144 \mathrm{hr}$ of culture.

${ }^{2}$ Initial immunization for diphtheria and tetanus at 2, 4, and 6 months of age. 
patients with SCID who are immunodeficient ( 0.4 versus 0.85 ; normal $=84.5 \pm 22$ ). Following transfusion, the red cell ADA activity rose as expected and then fell logarithmically over the next $2 \frac{1}{2}$ to 3 months to pretransfusion levels. Lymphocyte ADA as determined at high substrate concentrations was greater than that seen in four ADA-deficient SCID's (214 \pm 43 versus $136 \pm$ 66 ). Further biochemical quantitation and characterization of this residual $\mathrm{ADA}$ is reported elsewhere (21).

ATP and dATP Content of Lymphocytes. ATP content of Hypaque-Ficoll-separated mononuclear cell preparations was determined at 3, 4, 6, and 11 months of age. The patient's mononuclear cell ATP content was $22.3 \pm 3.6$ nmoles/mg protein (range, 18.8 to 24.5) compared to simultaneously determined normal ATP content of $23.2 \pm 3.0 \mathrm{nmoles} / \mathrm{mg}$ protein $(n=7)$. Inasmuch as this method determines dAPT as well as ATP content, we specifically determined dAPT content of mononuclear cells and found 1.9 pmoles $/ 10^{6}$ cells compared to normal of $2.9 \pm 1.0(n=7)$.

Cyclic AMP Content of Lymphocytes. Cyclic AMP content of Hypaque-Ficoll-separated mononuclear cell preparations was determined 16 months following the single red cell transfusion. Cyclic AMP in the patient's lymphocytes was 2.5 pmoles $/ 10^{6}$ cells. Cyclic AMP of normal cells was 2.5 to 5.0 pmoles $/ 10^{6}$ cells.

\section{DISCUSSION}

We have studied an individual with red blood cell-ADA deficiency who is now $3 \mathrm{yr}$ of age and who thus far has been a healthy, growing child. Our patient, similar to the !Kung tribesman (24), has a marked deficiency of ADA in his red cells but increased residual ADA activity in his mononuclear cells compared to patients with ADA-deficient SCID. More detailed and specific quantification and characterization (21) of ADA activity in cultured lymphoid lines and lymphocytes from both our patient and the !Kung reveals that they have 25 to $50 \%$ of normal activity compared to less than $2 \%$ in $\mathrm{ADA}^{-}$-SCID patients. However, this ADA is unstable in vitro. Thus, these two individuals compared with patients with ADA-deficient SCID appear to have a different mutation at the genetic locus for ADA and thus exemplify genetic heterogeneity for ADA deficienty. In the !Kung tribe, the mutant allele $\left(\mathrm{ADA}^{8}\right)$ was relatively common with a gene frequency of 0.11 . Therefore, approximately $1 \%$ of that population would be predicted to be homozygous deficient.

In the absence of ADA, the substrates adenosine and deoxyadenosine and their metabolites would be expected to accumulate in tissues and fluids. ADA-deficient individuals have indeed been reported to have elevated adenosine $(14,28,31)$, deoxyadenosine $(26,39)$, ATP $(31,36)$, deoxy-ATP $(7,9)$ and cyclic AMP (36) in their blood cells, plasma, and/or urine. In vitro studies have indicated that elevated concentrations of these compounds interfere with normal lymphocyte function. Adenosine and deoxyadenosine inhibit the proliferative response of lymphocytes to mitogens and growth of human lymphoid lines $(13,17,19,37$, 38). Accumulation of ATP can interfere with de novo purine biosynthesis and glycolysis (32). Increases in cyclic AMP have suppressive effects on inflammation (5), lymphocyte proliferative responses (19), and in vitro antibody synthesis (42). Increased deoxyadenosine, even more toxic for T-lymphocytes than is adenosine $(17,37,38)$, presumably results in increased concentrations of dATP $(29,41)$. Deoxy-ATP is a potent inhibitor of ribonucleotide reductase (33), activity of which is necessary for normal DNA synthesis. Although simulation of ADA deficiency (by the addition of the ADA inhibitors deoxycoformycin or EHNA to normal lymphocytes) in the absence of exogenous adenosine or deoxyadenosine does not appear to greatly affect the function of mature lymphocytes, it has been shown to interfere with the maturation of T-cell precursors in marrow cultures (2).

These effects in vitro may well have their counterparts in vivo because transfusion of some patients with $\mathrm{ADA}^{-}$-SCID with frozen, irradiated red blood cells containing normal ADA results in both lowering the concentration of several of these metabolites and a clinical and immunologic improvement $(20,40)$.
The plasma adenosine concentration in our patient at 10 months of age was comparable to levels measured in other ADA-deficient patients with SCID (1 to $4 \mu \mathrm{M})(7,26,31)$. However, subsequent determinations at 24 months of age revealed lower plasma adenosine of $0.6 \mu \mathrm{M}$ and $0.05 \mu \mathrm{M}$ at 30 months of age. Our patient has previously been found to have erythrocyte ATP and dATP not detectably different from normal (7). We have now found that his lymphocytes contain normal amounts of ATP, dATP and cyclic AMP as well. Thus, the residual ADA in his lymphocytes (and presumably other protein-synthesizing cells of the body) provide sufficient catalytic activity in vivo to prevent accumulation of toxic metabolites and for maintenance of normal immune function.

The one abnormality of immune function observed in our patient was the transient hypogammaglobulinemia. The clinical picture of $\mathrm{ADA}^{-}$-SCID would lead one to expect primarily a defect in cellular rather than humoral function $(16,27)$. However, at least two healthy children heterozygous for ADA deficiency have been observed to have transient hypogammaglobulinemia (35). It will be of interest to determine IgG content sequentially in siblings of ADA deficients to determine whether or not these were coincidental observations. Adenosine deaminase degrades not only adenosine and deoxyadenosine but also other naturally occurring modified adenosine derivatives (44). It is possible that alterations in the concentration of these latter compounds could affect B-cell maturation.

The major pathologic finding in our patient currently is the presence of a unilateral ureteropelvic obstruction. One previously reported totally ADA-deficient patient has also had a ureteropelvic junction anomaly (31). The finding of similar pathology in our patient could well be coincidental but might reflect an as yet undefined interference with normal renal development.

Although our patient is similar to the !Kung boy who has remained normal into his adolescent years, it remains to be seen if our patient will fare as well. A previously reported ADAdeficient child who eventually died of infections secondary to immunodeficiency was purportedly completely normal until 2 years of age except for absence of isoagglutinins and increased numbers of eosinophiles (11). Our patient has eosiniphilia, but isoagglutinins are present. Although we are encouraged by the absence of potentially toxic metabolites, the presence of substantial residual enzyme activity in lymphocytes, and the continued wellbeing of the partially ADA-deficient, adolescent !Kung tribesman, this sobering experience has led us to continue caring for our patient with a cautious but increasingly optimistic outlook.

Note added in proof: Our patient is currently 48 months of age and continues to grow and thrive normally. He has been immunized with live measles, mumps, and rubella vaccine without incident.

\section{REFERENCES AND NOTES}

1. Ackeret, C., Plüss, H. J. and Hitzig, W. H.: Hereditary severe combined immunodeficiency and adenosine deaminase deficiency. Pediatr. Res., 10:67 (1976).

2. Ballet, J-J., Insel, R., Merler, E., and Rosen, F. S.: Inhibition of maturation of human precursor lymphocytes by coformycin, an inhibitor of the enzyme adenosine deaminase. J. Exp. Med., 143: 1271 (1976).

3. Beutler, E.: Red cell metabolism. A manual of biochemical methods. 2nd ed. (Grune \& Stratton, Inc., New York, 1975).

4. Bianco, C. R., Patrick, R., and Nussenzweig, V.: A population of lymphocytes bearing a membrane receptor for antigen-antibody-complement complexes. $\mathbf{J}$. Exp. Med., 132: 702 (1970).

5. Bourne, H. R., Lichtenstein, L. M., Melmon, K. L., Henney, C. S., Weinstein, Y., and Shearer, G. M.: Modulation of inflammation and immunity by cyclic AMP. Science, 184: 19 (1974).

6. Catalona, W. J., Taylor, P. T., Rabson, A. S., and Chretien, P. B.: A method for dinitrochlorobenzene contact sensitization-a clinicopathologic study. N. Engl. J. Med., 286: 399 (1972).

7. Cohen, A., Hirschhorn, R., Horowitz, S. D., Rubinstein, A., Polmar, S. H., Hong. R., and Martin, D. W., Jr.: Deoxyadenosine triphosphate as a potentially toxic metabolite in adenosine deaminase deficiency. Proc. Natl. Acad. Sci. U. S. A. 75: 472 (1978).

8. Cohen, L., Holzman, R. S., Valentine, F. T., and Lawrence, H. S.: Requirement of precommitted cells as targets for the augmentation of lymphocyte proliferation by leukocyte dialysates. J. Exp. Med., 143: 791 (1976).

9. Coleman, M. S., Donofrio, J., Hutton, J. J., Hahn, L., Daoud, A., Lampkin, B. 
and Dyminski, J.: Identification and quantitation of adenine deoxynucleotides in erythrocytes of a patient with adenosine deaminase deficiency and severe combined immunodeficiency. J. Biol. Chem., 253: 1619 (1978).

Daddona, P. E., and Kelley, W. N.: Human adenosine deaminase-purification and subunit structure. J. Biol. Chem., 252: 110 (1977).

Giblett, E. R., Anderson, J. E., Cohen, F., Pollara, B., and Meuwissen, H. J. Adenosine-deaminase deficiency in two patients with severely impaired cellular immunity. Lancet, 2: 1067 (1972).

Gilman, A. G.: A protein binding assay for adenosine 3:5'-cyclic monophosphate. Proc. Natl. Acad. Sci. U. S. A., 67: 305 (1970)

Green, H., and Chan, T-S.: Pyrimidine starvation induced by adenosine in fibroblasts and lymphoid cells: role of adenosine deaminase. Science, 182: 836 (1973)

Hartwick, R. A., and Brown, P. R.: Selective analysis for adenosine using reversed-phase high-pressure liquid chromatography. J. Chromatogr., 143: 383 (1977).

irschhorn, R.: Adenosine deaminase deficiency and immunodeficiencies. Fed. Proc., 36: 2166 (1977).

Hirschhorn, R.: Defects of purine metabolism in immunodeficiency diseases. In R. S. Schwartz: Progress in Clinical Immunology, Vol. 3, p. 67 (Grune \& Stratton, Inc., New York, 1977).

Hirschhorn, R., Bajaj, S., Borkowsky, W., Kowalski, A., Hong, R., Rubinstein A., and Papageorgiou, P.: Differential inhibition of adenosine deaminase deficient peripheral blood lymphocytes and lymphoid line cells by deoxyadenosine and adenosine. Cell. Immunol., 42: 418 (1979).

Hirschhorn, R., Beratis, N., Rosen, F. S., Parkman, R., Stern, R., and Polmar, S. Adenosine-deaminase deficiency in a child diagnosed prenatally. Lancet, $I$ : 73: (1975)

Hirschhorn, R., Grossman, J., and Weissmann, G.: Effect of cyclic 3,5-adenosine monophosphate and theophylline on lymphocyte transformation. Proc. Soc. Exp. Biol. Med., 133: 1361 (1970).

Hirschhorn, R., Papageorgiou, P., Rubinstein, A., and Rosen, F. S.: Transfusion $v s$. bone marrow transplantation in combined immunodeficiency. Clin. Res. 27: 507A (1979)

Hirschhorn, R., Roegner, V., Jenkins, T., Seaman, C., Piomelli, S., and Borkowsky, W.: Erythrocyte adenosine deaminase deficiency without immunodeficiency: evidence for an unstable mutant enzyme. J. Clin. Invest., 64: 1130 (1979).

Hirschhorn, R., Vawter, G. F., Kirkpatrick, J. A., Jr. and Rosen F. S. Adenosine deaminase deficiency: frequency and comparative pathology in autosomally recessive severe combined immunodeficiency. Clin. Immunol. Immunopathol., 14: 107 (1979)

Hopkinson, D. A., Cook, P. J. L., and Harris, H.: Further data on the adenosine deaminase (ADA) polymorphism and a report of a new phenotype. Ann. Hum. Genet., 32: 361 (1969)

Jenkins, T., Rabson, A. R., Nurse, G. T., Lane, A. B., and Hopkinson, D. A. Deficiency of adenosine deaminase not associated with severe combined immunodeficiency. J. Pediatr., 89: 732 (1976).

Jondal, J., Wigzell, H., and Aiuti, F.: Human lymphocyte subpopulations Classification according to surface markers and/or functional characteristics. Transplant. Rev., 16: 163 (1973).

Kuttesch, J. F., Schmalstieg, F. C., and Nelson, J. A.: Analysis of adenosine anc other adenine compounds in patients with immunodeficiency diseases. J. Liquid Chromatogr., 1: 97 (1978).

Meuwissen, H. J., Pickering, R. J., Pollara, B., and Porter, I. H.: Combinec immunodeficiency disease and adenosine deaminase deficiency. A molecular defect. (Academic Press, Inc., New York, 1975).

Mills, G. C., Schmalstieg, F. C., Trimmer, K. B., Goldman, A. S., and Goldblum R. M.: Purine metabolism in adenosine deaminase deficiency. Proc. Natl. Acad. Sci. U. S. A., 73: 2867 (1976).

Mitchell, B. S., Mejias, E., Daddona, P. E., and Kelley, W. N.: Urinogenic immunodeficiency diseases: selective toxicity of deoxyribonucleosides for $\mathrm{T}$ cells. Proc. Natl. Acad. Sci. U. S. A., 75: 5011 (1978).

30. Pickering, R. J., Pollara, B., and Meuwissen, H. J.: Workshop on severe combined immunological deficiency disease and adenosine deaminase deficiency. Clin. Immunol. Immunopathol., 3: 301 (1974).

31. Polmar, S. H., Stern, R. C., Schwartz, A. L., Wetzler, E. M., Chase, P. A., and Hirschhorn, R.: Enzyme replacement therapy for adenosine deaminase deficiency and severe combined immunodeficiency. N. Engl. J. Med., 295: 1337 (1976).

32. Ramaiah, A.: Pasteur effect and phosphofructokinase. Curr. Top. Cell. Regul., 8: 297 (1974).

33. Reichard, P.: From deoxynucleotides to DNA synthesis. Fed. Proc., 37: 9 (1978),

34. Rosen, F. S.: Immunodeficiency. In: B. Benacerraf: Immunogenetics and Immunodeficiency. p. 230 (University Park Press, Baltimore, 1975).

35. Rosen, F. S. and Hitzig, W., personal communication.

36. Schmalstieg, F. C., Nelson, J. A., Mills, G. C., Monahan, T. M., Goldman, A. S., and Goldblum, R. M.: Increased purine nucleotides in adenosine deaminase deficient lymphocytes. J. Pediatr., 91: 48 (1977).

37. Seegmiller, J. E.: Mechanism of toxicity to T cells in deficiency of adenosine deaminase (ADA) or purine nucleoside phosphorylase (PNP): evidence for a role for deoxynucleosides. Fed. Proc., 37: 1465 (1978).

38. Simmonds, H. A., Panayi, G. S., and Corrigall, V.: A role for purine metabolism in the immune response: adenosine-deaminase activity and deoxyadenosine catabolism. Lancet, 1: 60 (1978).

39. Simmonds, H. A., Sahota, A., Potter, C. F., and Cameron, J. A.: Purine metabolism and immunodeficiency: urinary purine excretion as a diagnostic screening test in adenosine deaminase and purine nucleoside phosphorylase deficiency. Clin. Sci. Mol. Med., 54: 579 (1978).

40. Solter, A. W., and Handschumacher, R. E.: A rapid quantitative determination of deoxyribonucleoside triphosphates based on the enzymatic synthesis of DNA. Biochim. Biophys. Acta, 174: 585 (1969).

41. Ullman, B., Gudas, L. J., Cohen, A., and Martin, D. W., Jr.: Deoxyadenosine metabolism and cytotoxicity in cultured mouse T-lymphoma cells. A model for immunodeficiency disease. Cell, 14: 365 (1978).

42. Watson, J., Epstein, R., and Cohen, M.: Cyclic nucleotides as intracellular mediators of the expression of antigen-sensitive cells. Nature (Lond.), 246: 405 (1973).

43. Winchester, R. J., and Ross, G.: Methods for enumerating lumphocyte populations. In: N. R. Rose, H. Friedman: Manual of Clinical Immunology. p. 64. (American Society for Microbiology, 1976).

44. Zielke, C. L., and Suelter, C. H.: Purine nucleoside and purine nucleotide aminohydrolases. In: P. D. Boyer: The Enzymes. Vol. 4, Ed. 3 (Academic Preśs Inc., New York, 1971).

45. The authors would like to thank Dr. R. Winchester and Dr. T. Hoffman for their generous determination of T- and B-cell markers in addition to those reported here; Dr. S. Litwin for performing an assay of in vitro immunoglobulin synthesis; Dr. S. Kammerman and Joel Ross for initial determinations of cyclic AMP; Dr. Irma Gigli for complement determinations and Dr. S. Wolman for chromosome studies. Sharon Steinberg was of invaluable aid in both patient care and immunologic evaulation. As always we are grateful for the expert technical assistance of V. Roegner and T. Kowalski. Without the dedicated help of the nursing staff of the Special Care Unit of Bellevue Hospital and the Pediatric House Staff, these studies could not have been done.

46. Requests for reprints should be addressed to: Dr. R. Hirschhorn, Department of Medicine, New York University School of Medicine, 550 First Avenue, New York, N. Y. 10016 (USA).

47. This research was supported by National Foundation March of Dimes Grant 6 4. Dr. Borkowsky is supported by USPHS Training Grant 5 TOl AI 00005 19.

48. Received for publication June 18, 1979.

49. Accepted for publication November 9, 1979 